\section{Involvement of the Interferon Tau Gene in Maternal Recognition of Gestation in Sheep}

\author{
Conde-Hinojosa, M.P. ${ }^{1}$; Gallegos-Sánchez, J. ${ }^{1}$; Torres-Hernández, G. ${ }^{1}$; Salazar-Ortiz, J. ${ }^{2}$; \\ Glemente-Sánchez, F. ${ }^{3}$, Gortez-Romero, C. ${ }^{1,3, *}$
}

${ }^{1}$ Colegio de Postgraduados, Recursos Genéticos y Productividad-Ganadería, Campus Montecillo, Carretera México-Texcoco km. 36.5, Montecillo, Texcoco, 56230, Estado de México, México.

2 Colegio de Postgraduados, Innovación Agroalimentaria Sustentable, Campus Córdoba, carretera federal Córdoba-Veracruz km 348, Congregación Manuel León, 94946, Amatlán de los Reyes, Veracruz, México.

3 Colegio de Postgraduados, Innovación en Manejo de Recursos Naturales, Campus San Luis Potosí, Iturbide No. 73, Salinas de Hidalgo, 78600, San Luis Potosí, México.

* Corresponding author: ccortez@colpos.mx

Gitation: Conde-Hinojosa, M.P., Gallegos-Sánchez, J., TorresHernández, G., Salazar-Ortiz, J., Clemente-Sánchez, F., \& CortezRomero, C. (2021). Involvement of the Interferon Tau Gene in Maternal Recognition of Gestation in Sheep. Agro Productividad. https://doi.org/10.32854/ agrop.v14i8.2039

Editor in Chief: Dr. Jorge Cadena Iñiguez

Received: February, 2021. Accepted: July, 2021.

Estimated publication date: September, 2021

This work is licensed under a Creative Commons Attribution-NonCommercial 4.0 International license.

\section{ABSTRACT}

Objective: To describe the involvement of the interferon tau gene in the maternal recognition of pregnancy in sheep.

Design/Methodology/Approach: A search and analysis of the scientific documents retrieved from the Web of Science and Scopus databases related to the functions of the interferon tau gene in the maternal recognition of pregnancy in sheep were conducted.

Results: The interferon tau gene (IFN $\tau$ ) participates in maternal recognition of pregnancy to avoid possible rejection of the embryo, and supports the secretion of progesterone involved in preparing the endometrium for implantation; it also inhibits myometrial motility to maintain pregnancy. IFN $\tau$ stimulates the transcription of so-called interferon-stimulated genes (ISGs), which are the effectors of cell-autonomous antiviral defense. One of the representative members of ISGs is the interferon 15-stimulated gene (ISG15) which regulates endometrial receptivity at implantation, as well as survival, growth and development of the conceptus.

Study Limitations/Implications: Most embryonic losses occur between fertilization and maternal recognition of pregnancy. Understanding this issue is essential to understanding the possible causes of early pregnancy losses.

Findings/Conclusions: Considerable progress has been made in the discovery of how the IFN $\tau$ and ISG15 genes act in maternal recognition of gestation in sheep. However, some of the regulatory mechanisms involved remain poorly understood.

Keywords: IFN , ISG15, pregnancy, sheep. 


\section{INTRODUGTION}

A large portion of embryo loss originates during the first few weeks post conception. Most embryonic losses occur between fertilization and maternal recognition of gestation (Lonergan et al., 2016). Therefore, it is necessary to address this issue with research into the enigmas of embryo implantation (Miller et al., 2012). Evolving molecular insights have been used to study the process of maternal recognition of gestation, along with the molecular aspects of endometrial-embryo interactions, embryo development and implantation (Zohni et al., 2016). In ruminants, the establishment of adequate communication between the conceptus and the endometrium is essential for embryo implantation and subsequent successful placentation (Nakamura et al., 2020). This process involves the protein known as interferon tau $(\mathrm{IFN} \tau)$, initially called trophoblast protein or trophoblastin (Taverne \& Noakes, 2019), which is produced by its homologous gene now known as interferon tau or also known as TP-1 gene (Ealy \& Wooldridge, 2017). Some studies performed with ISG15 and IFN $\tau$ genes in vivo as well as in vitro have confirmed their importance in reproductive function in ruminants.

The IFN $\tau$ gene is involved in the maternal recognition of gestation to prevent possible rejection of the embryo and also supports progesterone secretion (D'Occhio et al., 2020). IFN $\tau$ molecules bind to cell surface receptors and initiate signal transduction; this activates the transcription of so-called ISGs which are the effectors of cell autonomous antiviral defense. One of the representative and well-studied ISG members with specific antiviral activities is the ISG15 gene (Wang et al., 2017). Given the critical importance of the process of maternal recognition of gestation, the objective of this review was to describe the implications of the interferon tau gene on maternal recognition of gestation in the ewe.

\section{Maternal Recognition of Gestation and Implantation}

Successful establishment of gestation involves ovulation of an oocyte, fertilization by a sperm and growth of the embryo in an environment conducive to normal development (Lonergan \& Sanchez, 2020). In several domestic species, the corpus luteum (CL) is important in regulating the periodicity of the estrus cycle (Hennebold, 2018), because the establishment of gestation requires that progesterone concentrations remain elevated. This results in negative feedback in the hypothalamus and the anterior pituitary gland with inhibition of follicular development. In several species, the placenta subsequently replaces or supplements the luteal source of progesterone (Taverne \& Noakes, 2019). The presence of a viable developing embryo prevents the CL from being destroyed (Pate, 2020) by the action of prostaglandin F2 $\alpha$ and thus inhibits the return to estrus. This phenomenon was defined in 1969 as the "maternal recognition of gestation" (Short, 1969).

The developing embryo eventually undergoes a process called conceptus elongation, which is a short-lived phenomenon resulting from remodeling and cellular migration of the developing embryo. Conceptus elongation begins on days 12-13 in ewes and is associated with implantation and recognition of gestation (Kasimanickam \& Kasimanickam, 2020). Around day 12, the embryo's trophoectoderm cells begin to secrete IFN $\tau$, the gestation recognition factor that overrides the uterine luteolytic mechanism to ensure maintenance of a functional CL (Lonergan \& Sanchez, 2020). Embryo implantation is a complex 
succession of events involving the attachment, adhesion, and invasion of the blastocyst in the endometrium ( $\mathrm{Liu} \& \mathrm{Li}, 2019$ ). Understanding this issue is basic to understanding the possible causes of early gestational losses (Taverne \& Noakes, 2019).

\section{Role of Progesterone (P4) in Maternal Recognition of Gestation}

Progesterone (P4) is secreted by the CL and placenta (Schumacher et al., 2014), and it is necessary for the establishment, maintenance and success of gestation (Wilson \& Mesiano, 2020). In the ewe it has two important functions: controlling the release of gonadotropinreleasing hormone (GnRH; Bartlewski et al., 2017) and maintaining gestation (Keller et al., 2019), because it is involved in preparing the endometrium for embryo implantation and it inhibits myometrial motility to maintain gestation (Mondal et al., 2017).

P4 along with interferon tau are essential for maintening gestation (Reynolds et al., 2014) and P4 blocks the proliferative effect of estrogen and induces the expression of genes that admit for the endometrium to accept embryo attachment (Halasz \& Szekeres-Bartho, 2013). High concentrations of $\mathrm{P} 4$ in maternal recognition of gestation have been associated with conceptus elongation and increased production of interferon tau, resulting in high gestation rates (Lonergan \& Forde, 2014). And low P4 concentrations are associated with lower fertility, reduced conceptus growth and elongation, decreased IFN $\tau$ production and lower gestation rates (Lonergan \& Sanchez, 2020).

\section{Interferons}

Interferons (IFNs) are widely expressed cytokines with antiviral properties (GonzalezNavajas et al., 2012). Mammalian IFNs are classified into Type I, Type II and Type III (Bayer et al., 2016). Type I IFNs are a group of highly related proteins that include interferons alpha $(\operatorname{IFN} \alpha)$, beta $(\operatorname{IFN} \beta)$, delta $(\operatorname{IFN} \delta)$, epsilon $(\operatorname{IFN} \varepsilon)$, tau $(\operatorname{IFN} \tau)$ and omega (IFN $\Omega$ ) (Dembic, 2015). Type II IFNs are represented by a single member, referred to as IFN gamma (IFN $\gamma$ ); and the type III class of IFNs contains three members that are known as IFN lambda (IFN $\lambda 1$, also known as IL-29), IFN $\lambda 2$ (also known as IL-28A) and IFNג3 (also known as IL-28B) (González-Navajas et al., 2012). IFNs are elements of the immune system and serve as a response to pathogens, have a key role in reducing pathogen replication and regulating immune responses (Snell et al., 2017).

\section{Interferon Tau (IFN $\tau)$ and its Involvement in Gestation Recognition}

Moor (1968) conducted research in ewes in which he demonstrated that the conceptus produces a protein. This protein is now known as interferon tau and is produced by its homologous gene IFN $\tau$ or also known as TP-1. The IFN $\tau$ gene interacts with uterine cells to direct the establishment and maintenance of gestation (Ealy \& Wooldridge, 2017). After 1979, purification of IFN $\tau$ revealed its anti-luteolytic activity to prevent CL regression in sheep (Bazer \& Thatcher, 2017). Originally, it was called ovine trophoblast protein (oTP-1) or trophoblastin. This substance has been shown to be a type I interferon, classified as ovine interferon tau (oIFN $\tau$ ); (Taverne \& Noakes, 2019). IFN $\tau$ is transiently produced by the ovine trophoectoderm, with expression being highest in the uterine epithelium between days 13 and 14 of the estrus cycle in ewes 
(Bazer \& Thatcher, 2017). Secretion of ovine IFN $\tau$ by the trophectoderm begins on day 10 and increases to peak concentrations between days 13 and 16; it then ceases to be secreted after day 21 of gestation (Fuller et al., 2019). The main effect of IFN $\tau$ on maternal recognition of gestation is to alter the dynamics of PGF2 $\alpha$ secretion in the early stage (Taverne \& Noakes, 2019).

$\mathrm{IFN}_{\tau}$ silences the transcription of receptors to estradiol type 1 (ERl) and, therefore, the expression of oxytocin receptors (ROX) that depend on ER1 receptors in the cells of the epithelial lumen and superficial glandular epithelial cells of the uterus to prevent the process of the endometrial luteolytic mechanism that requires pulsatile release of oxytocin-induced prostaglandins (Fleming et al., 2006). Presently, it is known that IFN $\tau$ serves as a vital mediator of early signaling between the developing embryo and the uterine endometrium in ruminants (Bazer et al., 2018). Progesterone and IFN $\tau$ operate mutually to induce expression of genes critical for conceptus development and implantation and in uterine glandular epithelial and stromal cells to induce expression of interferon-stimulated genes (ISG) such as: Interferon-induced myxovirus resistance protein (Mx1 and Mx2); Interferon-stimulated gene 15 (ISG15); 2'-5'-oligoadenylate synthetase 1 (OAS1); S-adenosyl methionine-containing radical domain 2 (RSAD2); Signal transducer and activator of transcription 1 (STAT1) and 2 (STAT2); Interferon regulatory factor 1 (IRF1) and 9 (IRF9; Bazer \& Thatcher, 2017). Figure 1 shows the mechanism of action of IFN $\tau$.

In addition to the paracrine effects of IFN $\tau$ secreted by the trophectoderm, ISGs have been found to be expressed in cellular components of the GL (Bazer \& Thatcher, 2017). The endocrine action of IFN $\tau$ has an impact on the CL to induce resistance to prostaglandin F2 $\alpha$ in its cells (Antoniazzi et al., 2013). It jointly enhances ISG15 expression in luteal cells (Oliveira et al., 2008) and alters immune cell functions within the CL to maintain its function and gestation (Shirasuna et al., 2015).

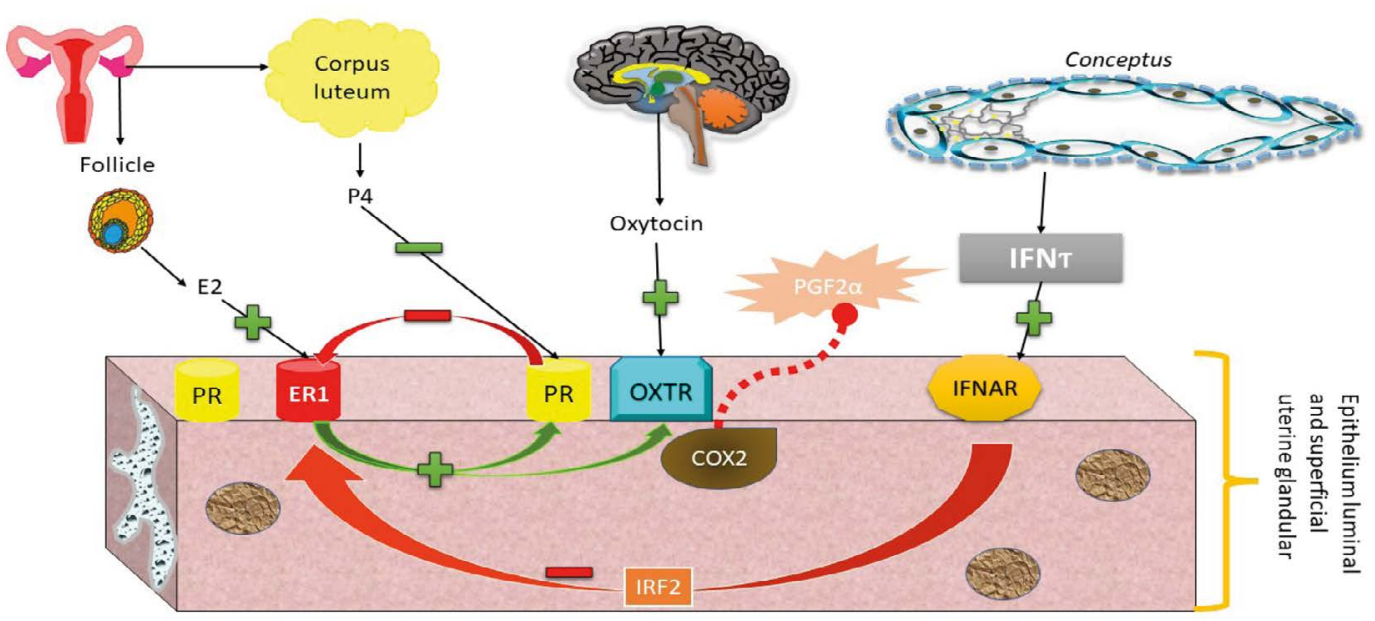

Figure 1. Mechanism of action of interferon tau (IFN $\tau)$. PR: progesterone receptor; ER1: estrogen receptor 1; OXTR: oxytocin receptor; IFNAR: interferon alfa receptor; PGF2 $\alpha$ : prostaglandin F2 alfa; E2: estradiol; P4: progesterone; COX2: cyclooxygenase 2 or prostaglandin-endoperoxide synthase 2; IRF2: interferon regulatory factor 2 . 


\section{Interferon-Stimulated Genes in Maternal Recognition of Gestation}

IFN $\tau$ also stimulates ISGs in glandular epithelium and endometrial stromal cells. Also, in peripheral tissues such as the CL and liver (Antoniazzi et al., 2013). Many ISGs have been hypothesized to play roles in implantation, placentation and conceptus development (Won, 2008). Some of the ISGs expressed in the ovine endometrium are shown below in Figure 2: MX1, MX2, ISG15, OAS1 and RSAD2, STAT1, STAT2 and IRF.

\section{Interferon-Stimulated Gene 15 (ISG 15)}

ISG15 is expressed in the ruminant uterus in response to IFN $\tau$ (Joyce et al., 2005). ISG15 was first identified in mouse tumor cells in which expression was regulated by a type I IFN (Farrell et al., 1979). Subsequently, Blomstrom et al. (1986) purified and characterized the $15 \mathrm{kDa}$ protein. The polypeptide was named ISG15 (Joyce et al., 2005). Austin et al. (2003) were the first to link it to the initiation of the gestation process by identifying the ISG15 protein secreted by the endometrium. ISG15 is a critical uterine response for the progressive processes of implantation and placentation, it was the first ubiquitin-like modifier (UBL) discovered and is stimulated with type I interferons and virus infections (Won, 2008). This ISG15 gene is synthesized in many cell types and secreted from monocytes and lymphocytes (Abidi \& Xirodimas, 2015), and it induces the synthesis and secretion of IFN $\gamma$ from lymphocyte B cells, implying that the role of ISG15 is like a cytokine that modulates the immune response (Kurz et al., 2005). Although the biological activities of ISG15 have not yet been fully elucidated, it is clear that the ISG15 gene modulates diverse cellular and physiological functions.

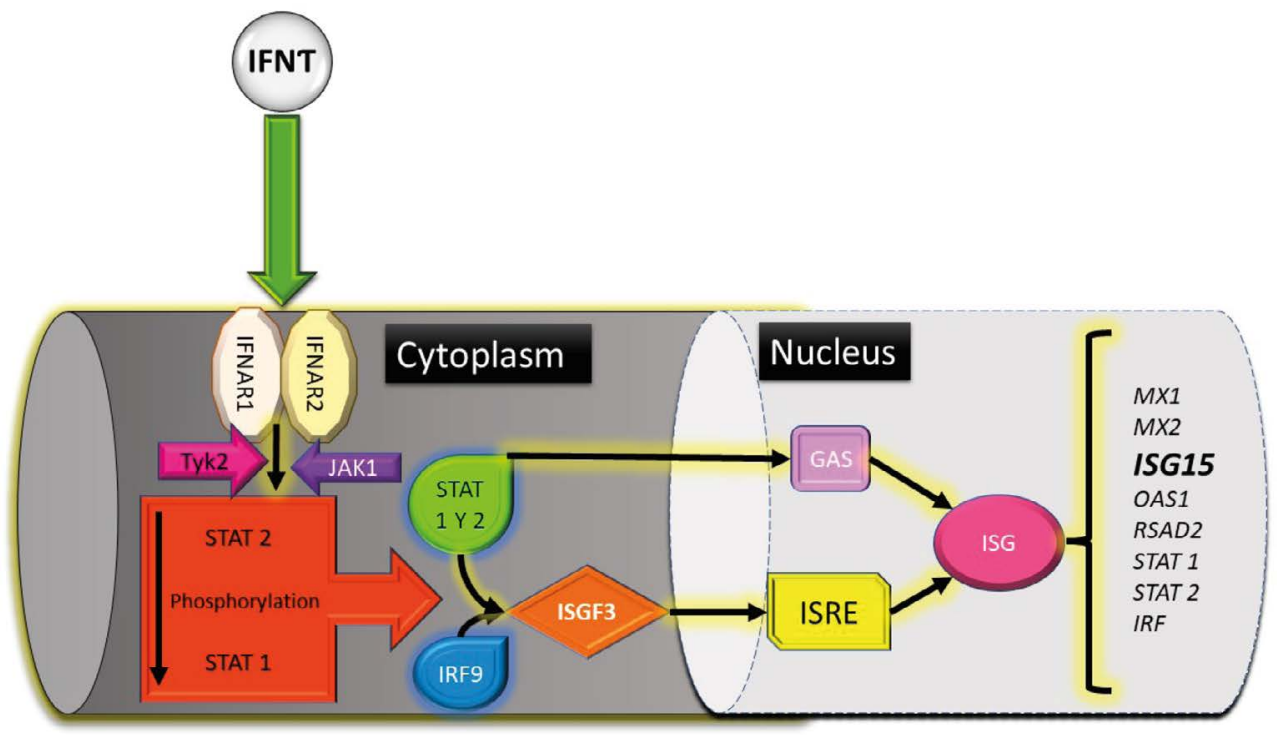

Figure 2. Signaling pathways for interferon tau in the ovine endometrial epithelium. IFN $\tau$ : Interferon tau; IFNAR1 and -2: interferon alfa receptor 1 and 2; activation of Janus kinase (JAK) members Tyk2 and JAK1; STAT1 and 2: signal transducer and activator of transcription 1 and 2; IRF9: interferon regulatory factor 9; ISGF3: interferon-stimulated gene factor 3; interferon-stimulated response element (ISRE); GAS: interferon gamma-activated site; ISG: interferon-stimulated genes; Mx: Mixovirus resistance 1 and 2; OAS1: 2 -5 oligoadenylate synthetase 1; RSAD2: Radical S-adenosyl methionine domain-containing protein 2; ISG15: interferon-stimulated gene 15; IRF: interferon regulatory factor. 


\section{Effect of the ISG15 Gene on Embryonic Development in Sheep}

The induction of ISG15 in response to IFN $\tau$ (Dzimianski et al., 2019) is mediated by an intracellular transduction signal system involving type I IFN receptors STAT1, STAT2 and IRF (Morales \& Lenschow, 2013). It is presumed that ISG15 regulates endometrial receptivity in implantation, survival, growth and development of the conceptus (embryo and associated extraembryonic membranes; Johnson et al., 1999). There is a significant increase in ISG15 gene expression in the ovine uterus at 15 days of gestation (Guo et al., 2020). Expression of this gene has been found in parts of the stroma along the uteroplacental interface in gestation. In addition, results from some studies demonstrate that ISG15-conjugated protein levels increase and then decrease during gestation (Alak et al., 2020), which indicates that it is a biologically active molecule that responds to IFN $\tau$ signaling from the conceptus and which temporarily targets proteins for regulation and modification associated with the gestation process (Jain et al., 2012). Endometrial ISG15 is not simply a consequence of an antiviral state induced by high levels of IFN $\tau$ in the lumen of ruminants at gestational recognition, but is a uterine response to conceptus processes; development, implantation and placentation (Joyce et al., 2005).

\section{GONGLUSIONS}

The IFN $\tau$ gene acts via paracrine in the endometrium and endocrine in the CL to exert its anti-luteolytic effects; this triggers progesterone production to be maintained and maternal recognition of gestation to occur. High concentrations of $\mathrm{P} 4$ in maternal recognition of gestation have been associated with lengthening of the conceptus and an increase in IFN $\tau$ production and higher gestation rates. IFN $\tau$ induces positive regulation of several ISG genes including the ISG15 gene, which is involved in maternal immunoregulation and other functions in early gestation in the ewe, such as regulation of endometrial receptivity during implantation.

\section{ACKNOWLEDGMENTS}

To the National Council for Science and Technology (Consejo Nacional de Ciencia y Tecnología, CONACyT) for funding the doctoral studies of the first author and to Colegio de Postgraduados for funding the research.

\section{REFERENGES}

Abidi, N., Xirodimas, D. P. (2015). Regulation of cancer-related pathways by protein NEDDylation and strategies for the use of NEDD8 inhibitors in the clinic. Endocrine-Related Cancer, 22(1), T55-70. Doi: 10.1530/ERC-14-0315

Alak, I., Hitit, M., Kose, M., Kaya, M. S., Ucar, E. H., Atli, Z., Atli, M. O. (2020). Relative abundance and localization of interferon-stimulated gene 15 mRNA transcript in intra- and extra-uterine tissues during the early stages of pregnancy in sheep. Animal Reproduction Science, 216, 106347. Doi: 10.1016/j. anireprosci.2020.106347

Antoniazzi, A. Q., Webb, B. T., Romero, J. J., Ashley, R. L., Smirnova, N. P., Henkes, L. E., Bott, R. C., Oliveira, J. F., Niswender, G. D., Bazer, F. W., Hansen, T. R. (2013). Endocrine Delivery of Interferon Tau Protects the Corpus Luteum from Prostaglandin F2 Alpha-Induced Luteolysis in Ewes. Biology of Reproduction, 88(6), 144. Doi: 10.1095/biolreprod.112.105684

Austin, K. J., Bany, B. M., Belden, E. L., Rempel, L. A., Cross, J. C., Hansen, T. R. (2003). Interferonstimulated gene-15 (Isg 15) expression is up-regulated in the mouse uterus in response to the implanting conceptus. Endocrinology, 144(7), 3107-3113. Doi:10.1210/en.2002-0031 
Bartlewski, P. M., Sohal, J., Paravinja, V., Baby, T., Oliveira, M. E. F., Murawski, M., Schwarz, T., Zieba, D. A., Keisler, D. H. (2017). Is progesterone the key regulatory factor behind ovulation rate in sheep? Domestic Animal Endocrinology, 58, 30-38. Doi: 10.1016/j.domaniend.2016.06.006

Bayer, A., Lennemann, N. J., Ouyang, Y., Bramley, J. C., Morosky, S., Marques, E. T. D. A., Cherry, S., Sadovsky, Y., Coyne, C. B. (2016). Type III Interferons Produced by Human Placental Trophoblasts Confer Protection against Zika Virus Infection. Cell Host E Microbe, 19(5), 705-712. Doi: 10.1016/j. chom.2016.03.008

Bazer, F. W., Burghardt, R. G., Johnson, G. A., Spencer, T. E., Wu, G. (2018). Mechanisms for the establishment and maintenance of pregnancy: Synergies from scientific collaborations $\dagger$. Biology of Reproduction, 99(1), 225-241. Doi: 10.1093/biolre/ioy047

Bazer, F. W., Thatcher, W. W. (2017). Chronicling the discovery of interferon tau. Reproduction, 154(5), F11F20. Doi: 10.1530/REP-17-0257

Blomstrom, D. C., Fahey, D., Kutny, R., Korant, B. D., Knight, E. (1986). Molecular characterization of the interferon-induced 15-kDa protein. Molecular cloning and nucleotide and amino acid sequence. Journal of Biological Chemistry, 261(19), 8811-8816. Doi: 10.1016/S0021-9258(19)84453-8

Dembic, Z. (2015). Cytokines of the Immune System. In: The Cytokines of the Immune System (pp. 123-142). Elsevier. Doi: 10.1016/B978-0-12-419998-9.00005-5

D’Occhio, M. J., Campanile, G., Baruselli, P. S. (2020). Transforming growth factor- superfamily and interferon- in ovarian function and embryo development in female cattle: Review of biology and application. Reproduction, Fertility and Development, 32(6), 539-552. Doi: 10.1071/RD19123

Dzimianski, J. V., Scholte, F. E. M., Bergeron, É., Pegan, S. D. (2019). ISG15: It's Complicated. Journal of Molecular Biology, 431(21), 4203-4216. Doi: 10.1016/j.jmb.2019.03.013

Ealy, A. D., Wooldridge, L. K. (2017). The evolution of interferon-tau. Reproduction, 154(5), F1-F10. Doi: 10.1530/REP-17-0292

Farrell, P. J., Broeze, R. J., Lengyel, P. (1979). Accumulation of an mRNA and protein in interferon-treated Ehrlich ascites tumour cells. Nature, 279(5713), 523-525. Doi: 10.1038/279523a0

Fleming, J. G. W., Spencer, T. E., Safe, S. H., Bazer, F. W. (2006). Estrogen Regulates Transcription of the Ovine Oxytocin Receptor Gene through GC-Rich SP1 Promoter Elements. Endocrinology, 147(2), 899911. Doi: 10.1210/en.2005-1120

Fuller, W. B., Jinyoung, K. J., Gwonhwa, S. G., Hakhyun, K. H., Guoyao, W. G., Johnson, G. A., Vallet, J. L. (2019). Roles of selected nutrients in development of the porcine conceptus during pregnancy. Bioscientifica Proceedings. Doi: 10.1530/biosciprocs.19.0016

González-Navajas, J. M., Lee,J., David, M., Raz, E. (2012). Immunomodulatory functions of type I interferons. Nature Reviewes Immunology, 12(2), 125-135. Doi: 10.1038/nri3133

Guo, Y., Song, Z., Cheng, X., Wang, Y., Luo, X., An, R., Wang, J., Gao, M. (2020). Molecular and functional characterization of ovis aries IFN-epsilon. Molecular Immunology, 119, 1-7. Doi: 10.1016/j. molimm.2020.01.001

Halasz, M., Szekeres-Bartho, J. (2013). The role of progesterone in implantation and trophoblast invasion. Journal of Reproductive Immunology, 97(1), 43-50. Doi: 10.1016/j.jri.2012.10.011

Jain, A., Baviskar, P. S., Kandasamy, S., Kumar, R., Singh, R., Kumar, S., Agarwal, S. K., Joshi, P., Mitra, A. (2012). Interferon stimulated gene 15 (ISG15): Molecular characterization and expression profile in endometrium of buffalo (Bubalus bubalis). Animal Reproduction Science, 133(3-4), 159-168. Doi: 10.1016/j.anireprosci.2012.06.023

Johnson, G. A., Spencer, T. E., Hansen, T. R., Austin, K. J., Burghardt, R. C., Bazer, F. W. (1999). Expression of the Interferon Tau Inducible Ubiquitin Cross-Reactive Protein in the Ovine Uterus. Biology of Reproduction, 61(1), 312-318. Doi: 10.1095/biolreprod61.1.312

Joyce, M. M., White, F. J., Burghardt, R. C., Muñiz, J. J., Spencer, T. E., Bazer, F. W., Johnson, G. A. (2005). Interferon Stimulated Gene 15 Conjugates to Endometrial Cytosolic Proteins and Is Expressed at the Uterine-Placental Interface throughout Pregnancy in Sheep. Endocrinology, 146(2), 675-684. Doi: 10.1210/en.2004-1224

Kasimanickam, R. K., Kasimanickam, V. R. (2020). IFNT, ISGs, PPARs, RXRs and MUC1 in day 16 embryo and endometrium of repeat-breeder cows, with or without subclinical endometritis. Theriogenology, 158 , 39-49. Doi: 10.1016/j.theriogenology.2020.09.001

Keller, M., Vandenberg, L. N., Charlier, T. D. (2019). The parental brain and behavior: A target for endocrine disruption. Frontiers in Neuroendocrinology, 54, 100765. Doi: 10.1016/j.yfrne.2019.100765

Kurz, T., Ozlü, N., Rudolf, F., O’Rourke, S. M., Luke, B., Hofmann, K., Hyman, A. A., Bowerman, B., Peter, M. (2005). The conserved protein DCN-1/Dcnlp is required for cullin neddylation in C. elegans and $S$. cerevisiae. Nature, 435(7046), 1257-1261. Doi: 10.1038/nature03662 
Liu, F., Li, R. (2019). The Role of Neuroendocrine in Embryo Implantation. En B. Wu \& H. L. Feng (Eds.), Embryology-Theory and Practice. IntechOpen. Doi: 10.5772/intechopen.87863

Lonergan, P., Forde, N. (2014). Maternal-embryo interaction leading up to the initiation of implantation of pregnancy in cattle. Animal: An International Journal of Animal Bioscience, 8 Suppl 1, 64-69. Doi: 10.1017/ S1751731114000470

Lonergan, P., Sánchez, J. M. (2020). Symposium review: Progesterone effects on early embryo development in cattle. Journal of Dairy Science, 103(9), 8698-8707. Doi: 10.3168/jds.2020-18583

Lonergan, Pat, Forde, N., Spencer, T. (2016). Role of progesterone in embryo development in cattle. Reproduction, Fertility, and Development, 28(2), 66-74. Doi: 10.1071/RD15326

Miller, P. B., Parnell, B. A., Bushnell, G., Tallman, N., Forstein, D. A., Higdon, H. L., Kitawaki, J., Lessey, B. A. (2012). Endometrial receptivity defects during IVF cycles with and without letrozole. Human Reproduction, 27(3), 881-888. Doi: 10.1093/humrep/der452

Mondal, S., Mor, A., Reddy, I. J. (2017). Factors/Genes in Maternal Recognition of Pregnancy. In: Current Developments in Biotechnology and Bioengineering (pp. 597-630). Elsevier.Doi: 10.1016/B978-0-44463660-7.00023-1

Moor, R. M. (1968). Effect of Embryo on Corpus Luteum Function. Journal of Animal Science, 27, 97-118. Doi: 10.2527/animalsci1968.27Supplement_197x

Morales, D. J., Lenschow, D. J. (2013). The Antiviral Activities of ISG15. Journal of Molecular Biology, 425(24), 4995-5008. Doi: 10.1016/j.jmb.2013.09.041

Nakamura, K., Kusama, K., Suda, Y., Fujiwara, H., Hori, M., Imakawa, K. (2020). Emerging Role of Extracellular Vesicles in Embryo-Maternal Communication throughout Implantation Processes. International Journal of Molecular Sciences, 21(15), 5523. Doi: 10.3390/ijms21155523

Oliveira, J. F., Henkes, L. E., Ashley, R. L., Purcell, S. H., Smirnova, N. P., Veeramachaneni, D. N. R., Anthony, R. V., \& Hansen, T. R. (2008). Expression of Interferon(IFN)-Stimulated Genes in Extrauterine Tissues during Early Pregnancy in Sheep Is the Consequence of Endocrine IFN- Release from the Uterine Vein. Endocrinology, 149(3), 1252-1259. Doi: 10.1210/en.2007-0863

Pate, J. L. (2020). Roadmap to pregnancy during the period of maternal recognition in the cow: Changes within the corpus luteum associated with luteal rescue. Theriogenology, 150, 294-301. Doi: 10.1016/j. theriogenology.2020.01.074

Reynolds, L. P., Borowicz, P. P., Palmieri, C., Grazul-Bilska, A. T. (2014). Placental Vascular Defects in Compromised Pregnancies: Effects of Assisted Reproductive Technologies and Other Maternal Stressors. In: L. Zhang \& C. A. Ducsay (Eds.), Advances in Fetal and Neonatal Physiology, 814, 193-204. Springer New York. Doi: 10.1007/978-1-4939-1031-1_17

Schumacher, M., Mattern, G., Ghoumari, A., Oudinet, J. P., Liere, P., Labombarda, F., Sitruk-Ware, R., De Nicola, A. F., Guennoun, R. (2014). Revisiting the roles of progesterone and allopregnanolone in the nervous system: Resurgence of the progesterone receptors. Progress in Neurobiology, 113, 6-39. Doi: 10.1016/j.pneurobio.2013.09.004

Shirasuna, K., Matsumoto, H., Matsuyama, S., Kimura, K., Bollwein, H., \& Miyamoto, A. (2015). Possible role of interferon tau on the bovine corpus luteum and neutrophils during the early pregnancy. Reproduction, 150(3), 217-225. Doi: 10.1530/REP-15-0085

Short, R. V. (1969). Implantation and the Maternal Recognition of Pregnancy. In: G. E. W. Wolstenholme \& M. O’Connor (Eds.), Novartis Foundation Symposia (pp. 2-31). John Wiley \& Sons, Ltd. Doi: /10.1002/9780470719688.ch2

Snell, L. M., McGaha, T. L., Brooks, D. G. (2017). Type I Interferon in Chronic Virus Infection and Cancer. Trends in Immunology, 38(8), 542-557. Doi: 10.1016/j.it.2017.05.005

Taverne, M., \& Noakes, D. E. (2019). Pregnancy and Its Diagnosis. In: Veterinary Reproduction and Obstetrics, 78-114. Elsevier. Doi: 10.1016/B978-0-7020-7233-8.00005-7

Wang, W., Xu, L., Su, J., Peppelenbosch, M. P., \& Pan, Q. (2017). Transcriptional Regulation of Antiviral Interferon-Stimulated Genes. Trends in Microbiology, 25(7), 573-584. Doi: 10.1016/j.tim.2017.01.001

Wilson, R. A., \& Mesiano, S. A. (2020). Progesterone signaling in myometrial cells: Role in human pregnancy and parturition. Current Opinion in Physiology, 13, 117-122. Doi: 10.1016/j.cophys.2019.09.007

Won A. H. (2008). Progesterone and interferon tau regulated genes in the endometrium of the ovine uterus and expression of interferon stimulated genes in the corpus luteum during early pregnancy in sheep. These of Master of Science. Texas A\&M University College Station.

Zohni, K. M., Gat, I., \& Librach, G. (2016). Recurrent implantation failure: A comprehensive review. Minerva Ginecologica, 68(6), 653-667. 